Jurnal Pendidikan Ekonomi: Jurnal Ilmiah Ilmu Pendidikan, Ilmu Ekonomi, dan Ilmu Sosial ISSN 1907-9990 | E-ISSN 2548-7175 | Volume 14 Nomer 1 (2020)

DOI: $10.19184 / j p e . v 14 i 1.12035$

\title{
STRATEGI TRANSFORMASI NILAI KEWIRAUSAHAAN DI PONDOK PESANTREN MABADI'UL IHSAN KABUPATEN BANYUWANGI
}

\author{
Diana Cholida ${ }^{1}$, Sri Wahyuni ${ }^{1}$, Joko Widodo ${ }^{1}$ \\ ${ }^{1}$ Pendidikan Ekonomi, Fakultas Keguruan dan Ilmu Pendidikan, Universitas Jember \\ Jln. Kalimantan 37, Jember 68121 \\ E-mail: dianacholida1996@gmail.com
}

\begin{abstract}
Abstark
Nilai kewirausahaan dapat ditransformasikan pada siapa saja dan dimana saja termasuk di pondok pesantren. Seiring dengan perkembangan teknologi yang semakin maju, pondok pesantren melakukan inovasi baru dengan memberikan bekal kewirausahaan. Pemberian bekal kewirausahaan ini melatih santri untuk berwirausaha dalam mengaktualisasikan kemampuannya sebagai seorang wirausaha atau enterpreneurship. Penelitian ini merupakan penelitian kualitatif dengan pendekatan deskriptif yang bertujuan untuk mendeskripsikan strategi yang dilakukan Pondok Pesantren Mabadi'ul Ihsan Banyuwangi dalam transformasi nilai kewirausahaan santri. Subyek penelitian ini yaitu pengelola Pondok Pesantren Mabadi'ul Ihsan dan informan 4 santri, ustad dan ustadzah. Metode pengumpulan data yang digunakan terdiri dari metode wawancara, dokumen, dan observasi. Metode analisis data yang digunakan adalah dengan cara reduksi data, penyajian data, dan penarikan kesimpulan.

Hasil dari penelitian menunjukkan bahwa Nilai-nilai kewirausahaan yang ditransformasikan pada santri adalah: (a) percaya diri, (b) berani mengambil risiko, (c) bertanggung jawab, (d) dapat menjadi pemimpin, (e) berorientasi ke masa depan, (f) keorisinilan. Adapun strategi Pondok Pesantren Mabadi'ul Ihsan dalam mentrasformasikan nilai-nilai kewirausahaan sebagai berikut: Pertama, nilainilai kewirausahaan ditransformasikan melalui Pengintegrasian mata pelajaran umum seperti mata pelajaran Matematika, IPA, Bahasa Indonesia, Agama dan Ekonomi. Kedua, nilai-nilai kewirausahaan ditransformasikan melalui Business Center dengan cara melibatkan santri pada unit usaha Mihamart dan kantin pesantren. Ketiga,nilai-nilai kewirausahaan ditransformasikan melalui Ekstrakurikuler, diadakan pelatihan keterampilan batik, pengelolaan makanan ringan dan minuman dari sari buah. Keempat, nilainilai kewirausahaan ditransformasikan melalui Unit produksi, santri mengelola usaha produksi milik pesantren seperti Miha batik, makanan ringan dan minuman sari buah.
\end{abstract}

Kata Kunci: Transformasi, Nilai-nilai kewirausahaan

\section{PENDAHULUAN}

Pondok pesantren merupakan salah satu lembaga pendidikan non formal yang tersebar di Indonesia, sekaligus sebagai tempat santri untuk mempelajari ilmu agama islam. Pondok pesantren awalnya hanya memiliki sistem pendidikan salaf dengan metode pembelajaran yang masih tradisional atau non klasikal. Seiring dengan perkembangan zaman disamping mempertahankan sistem ketradisionalannya, pondok pesantren mulai mengembangkan sistem pendidikan klasikal yaitu mulai dimasukannya pendidikan mulai tingkat SD, SMP, SMA ke dalam pondok pesantren. perkembangan ini dimaksudkan untuk mengantisipasi perubahan yang terjadi di masyarakat dikarenanya semakin majunya bidang pendidikan.

Perkembangan dunia yang semakin maju dan modern menjadikan generasi muda saat ini banyak menyimpang terutama dari segi akhlak dan moralnya dan melemahnya nilai dan norma positif semakin menurun, sehingga menyebabkan tawuran antar pelajar. Hal ini perlu adanya perubahan yang harus diperbaiki dan disesuaikan dengan keadaan dunia pada saat ini, dengan usia yang masih produktif untuk menerima ilmu pengetahuan salah satunya adalah ilmu wirausaha, maka lembaga pendidikan baik pendidikan formal maupun non formal penting dalam menyikapi tamatan yang siap untuk berwirausaha yang memiliki perilaku yang tidak menyimpang. Menyikapi tamatan yang memiliki perilaku yang baik lembaga pendidikan non 
Jurnal Pendidikan Ekonomi: Jurnal Ilmiah Ilmu Pendidikan, Ilmu Ekonomi, dan Ilmu Sosial ISSN 1907-9990 | E-ISSN 2548-7175 | Volume 14 Nomer 1 (2020)

DOI: 10.19184/jpe.v14i1.12035

formal yaitu pesantren mulai melakukan berbagai macam perubahan selain mengajarkan ilmu agama, ilmu umum, juga memberikan bekal kewirausahaan yang bersifat aplikatif dan siap kerja.

Salah satu pondok pesantren yang telah mentransformasikan nilai-nilai kewirausahaan kepada santri adalah pondok pesantren Mabadi'ul Ihsan, bertempat di J1. KH. Achmad Musayyidi Desa Karang Doro Kecamatan Tegalsari Kabupaten Banyuwangi. Meski fokus utama tetap mengajarkan agama islam secara menyeluruh, pengasuh pondok pesantren Mabadi'ul Ihsan memberikan wadah bagi santri terkait bekal kewirausahaan.

Kegiatan kewirausahaan di Pondok Pesantren Mabadi'ul Ihsan memilki tempat khusus untuk menanamkan nilai-nilai kewirausahaan melalui pertama integrasi mata pelajaran, kedua business center yaitu Mihaamart,Mihamart merupakan unit usaha yang berada dilingkungan pondok pesantren Mabadi'ul Ihsan, dan menjadi wadah bagi santri untuk berwirausaha. Selain pengelolaan Mihamart terdapat kantin yang disediakan oleh pondok pesantren yang melibatkan santri dalam pengelolaannya. ketiga ekstrakurikuler yaitu pelatihan keterampilan membatik dan membuat sari buah asli yang di bimbing langsung oleh ustad dan ustadzah. Keempat, unit produksi yang melibatkan santri dalam pengelolaan batik dan minuman sari buah. Keberadaan business center dan unit produksi memegang peranan yang sangat penting karena tempat dimana santri dilatih untuk berwirausaha dalam rangka mengaktualisasikan kemampuannya sebagai seorang wirausahawan dan sebagai tempat untuk mengembangkan nilai-nilai kewirausahaan. Nilai mempunyai makna penting dalam mempengaruhi sikap individu, Suryana (2006:37) niali-nilai kewirausahaan dapat dilihat dari watak, jiwa dan perilaku. Secara pragmatik kewirausahaan dapat dilihat dari unsur-unsur sebagai berikut: bekerja keras, tegas, mengutamakan prestasi, keberanian, mengambil risiko, produktivitas, kreativitas, inovatif, komitmen dan kemampuan mencari peluang. Nilai moralistik meliputi: keyakinan diri, kehormatan, kepercayaan, kerja sama, kejujuran, keteladanan dan keutamaan. Terdapat nilainilai hakiki dari kewirausahaan diantaranya: percaya diri, berorientasi pada tugas dan hasil, keberanian mengambil risiko, kepemimpinan, berorientasi ke masa depan, keorisinilan.

Berdasarkan pemaparan di atas, maka peneliti bermaksud mengadakan penelitian yang bertujuan untuk mendeskripsikan strategi transformasi nilai kewirausahaan di Pondok Pesantren Mabadi'ul Ihsan Kabupaten Banyuwangi.

\section{METODE PENELITIAN}

Penelitian ini menggunakan jenis penelitian deskriptif dengan pendekatan kualitatif. Lokasi penelitian ini dilaksanakan di Pondok Pesantren Mabadi'ul Ihsan yang terletak di Jl. KH. Achmad Musayyidi Kecamatan Tegalsari Kabupaten Banyuwangi. Penentuan lokasi penelitian ini menggunakan metode purposive area yaitu lokasi penelitian yang ditentukan secara sengaja. Adapun pertimbangan peneliti memilih Pondok Pesantren Mabadi'ul Ihsan karena Pondok Pesantren Mabadi'ul Ihsan merupakan salah satu pondok pesantren yang mentrasfer nilai- nilai kewirausahaan kepada santrinya dengan cara melibatkan santri dalam kegiatan program kewirausahaan. Subjek dalam penelitian ini adalah pengelola Pondok Pesantren Mabadi'ul Ihsan ibu Nyai Hj. Murtasimah, ustad Eko Wahyudi dan ustadzah Faiqotun Hadiah yang juga berlaku sebagai informan utama, sedangkan informan tambahan yaitu santri yang ikut dalam program kewirausahaan. Metode pengumpulan data yang digunakan terdiri dari metode wawancara, observasi, dan dokumentasi. Analisis data yang digunakan yaitu reduksi data, penyajian data, dan penarikan kesimpulan.

\section{HASIL DAN PEMBAHASAN}

\section{Hasil Penelitian}

\section{Strategi dalam Mentransformasikan Nilai-Nilai Kewirausahaan}

Pondok pesantren mulai melakukan berbagai strategi untuk menjadikan para santrinya memiliki kemampuan yang lebih dalam bidang apapun. Hal ini merupakan inovasi baru yang diberikan oleh pondok pesantren untuk membentuk santri yang memiliki jiwa wirausahawan. 
Pelaksanaan strategi yang tepat, akan mudah untuk mentrasfer nilai-nilai kewirausahaan kepada santri. Adapun strategi transformasi sendiri merupakan cara, kiat dan taktik yang dirancang untuk mentrasfer suatu nilai kewirausahaan agar tujuan-tujuan tersebut dapat terwujud. Berdasarkan hasil penelitian ditemukan bahwa strategi di pondok pesantren Mabadi'ul Ihsan dapat dijelaskan sebagai berikut:

\section{Integrasi Mata Pelajaran}

Integrasi dalam mata pelajaran merupakan proses penginternalisasian nilai-nilai kewirausahaan dalam kegiatan pembelajaran. Melalui integrasi, diharapkan santri memperoleh kesandaran betapa pentingnya nilai-nilai kewirausahaan, terbentuknya karakter wirausaha dan pembiasaan dalam kehidupan sehari-hari. Integrasi mata pelajaran yang dilakukan oleh ustad dan ustadzah dalam kegiatan kewirausahaan didalamnya terdapat mata pelajaran lain yang dikaitkan. Pembelajaran konsep-konsep kewirausahaan diintegrasikan dengan mata pelajaran umum seperti Matematika, IPA, Bahasa Indonesia, Agama, Ekonomi disesuaikan dengan karakteristik suatu pembelajaran tertentu. pengintegrasian konsep-konsep kewirausahaan di pesantren disesuaikan dengan sifat dan karakteristik muatan pelajaran yang harus dicapai santri. Pada mata pelajaran agama guru mengajarkan tentang bertutur kata yang baik, bersikap jujur, berbagi atau bersedekah dari hasil penjualan yang di dapatkan oleh santri.

\section{Business Center}

Business center merupakan kegiatan usaha di sekolah, dimana siswa secara langsung melakukan kegiatan perdagangan atau retail. Business center sebagai wadah untuk menanamkan nilai-nilai kewirausahaan kepada santri, pondok pesantren Mabadi'ul Ihsan dalam mentrasfer nilai kewirausahaan yaitu dengan melibatkan santri dalam unit usaha yang ada di pesantren diantaranya Mihamart dan kantin pesantren. Kegiatan business center ini masing-masing santri bertanggung jawa atas tugasnya, bagian tugas dari masing-masing santri yaitu bagian kasir untuk setiap harinya mencatat hasil keseluruhan pendapatan dan dilaporkan kepada pengasuh untuk setiap minggunya. Petugas bagian pramuniaga memiliki tugas untuk display barang dagangan. Untuk petugas bagian pembelian atau gudang yaitu mulai dari memasukkan transaksi setiap pembelian barang sekaligus tanggal jatuh tempo, mengecek barang datang sesuai dengan nota pembelian dan menyesuaikan harga jual dengan harga beli jika ada kenaikan atau penurunan harga.

\section{Ekstrakurikuler}

Ekstrakurikuler merupakan kegiatan yang berada di luar program yang tertulis di dalam kurikulum, kegiatan ini memberikan keleluasaan waktu dan memberikan kebebasan pada siswa, terutama dalam menentukan jenis kegiatan yang sesuai dengan bakat serta minat siswa. Pondok pesantren Mabadi'ul Ihsan memberikan pelatihan keterampilan kepada santri diantaranya pelatihan batik dan pengelolaan makanan dan minuman sari buah. Pelaksanaan pelatihan keterampilan ini dimulai dari persiapan guru menyiapkan materi yang berasal dari buku, internet dan dari video youtube. Kemudian santri mulai mempraktekkannya, dalam proses pelatihan ini santri diberikan keluasan untuk mendesain dengan sekreatif mungkin. Hasil karya dari kegiatan pelatihan batik ini kemudian dipajang di etalase pesantren dengan tujuan untuk memotivasi santri lain agar meningkatkan jiwa kreatifnya.

\section{Unit Produksi}

Unit produksi merupakan aktivitas bisnis yang dilakukan secara berkesinambungan dalam mengelola sumber daya sekolah, sehingga dapat menghasilkan produk dan jasa yang mendatangkan keuntungan. pondok pesantren Mabadi'ul Ihsan dalam mentrasfer nilai kewirausahaan yaitu santri diikutsertakan dalam proses pengelolaan produksi, santri diberi tanggung jawab untuk mengelola unit produksi yang berada di pesantren diantaranya unit produksi miha batik dan pengelolaan makanan dan minuman sari buah. Unit produksi ini bukan hanya sekedar label, tetapi memang karya para santri Pondok Pesantren Mabadi'ul Ihsan. Banyak inovasi-inovasi batik yang diciptakan oleh santri diantaranya batik sego tempong, batik 
sekar jagad, batik tulis manuk mangkring. Tidak cukup dengan membuat batik, produk miha batik ini, juga diperkenalkan kepada konsumen dengan cara konsumen dibebaskan untuk memilih desain sesuai dengan yang diinginkannya, hal tersebut dilakukan dengan tujuan untuk menarik konsumen. Selain itu miha batik melakukan promosi melalui berbagai macam cara diantaranya pemasaran langsung yang dipasarkan pada unit usaha yang ada di pesantren seperti mihamart.

\section{Nilai-Nilai Kewirausahaan yang di Transformasikan pada Santri}

Selain memberikan bekal ketrampilan, program kewirausahaan di pondok pesantren Mabadi'ul Ihsan juga digunakan sebagai sarana dalam menanamkan nilai-nilai kewirausahaan kepada santri. Pelaksanaan pembelajaran kewirausahaan sebagai upaya menanamkan nilai-nilai wirausaha, hal ini juga disampaikan oleh ustadzah sebagai berikut:

"selain memberikan ilmu ketrampilan, program kewirausahaan ini juga untuk menanamkan karakter seorang wirausaha. Jadi santri tidak hanya tahu dan mempraktikkan bisnis saja, tetapi santri juga lebih berani, disiplin, kreatif, dapat bertanggung jawab, serta dapat menjadi pemimpin bagi teman-temannya yang lain" ( $F, 25$ tahun)

Pengasuh pondok pesantren Mabadi'ul Ihsan mempunyai harapan bahwa setelah santri mendapatkan bekal kewirausahaan, maka santri mempunyai ketrampilan yang disesuaikan dengan bakatnya dan sikap santri berubah menjadi lebih disiplin, berani bertanggung jawab, dapat menjadi pemimpin dan dapat bekerja sama dengan baik.

Berdasarkan hasil penelitian ditemukan bahwa nilai-nilai kewirausahaan di pondok pesantren Mabadi'ul Ihsan dapat dijelaskan sebagai berikut:

\section{Menumbuhkan Jiwa Kepemimpinan pada Santri melalui Program Kewirausahaan}

Salah satu cara mentor mengajarkan tanggung jawab adalah dengan melibatkan santri mengelola unit usaha yang ada di pesantren yaitu mengolah minuman sari buah dari buahbuahan. Dengan mentor memberikan modal kepada santri, santri diminta untuk menjalankan bisnisnya yaitu membuat minuman sari buah yang kemudian produk minuman sari buah tersebut dipasarkan. Setelah pemasaran santri membuat laporan keuangannya. Harapannya modal yang diberikan kepada santri dapat dikembalikan setelah santri selesai berjualan. Apabila santri tidak menjalankan tugasnya dengan sungguh-sungguh dengan penuh rasa tanggung jawab, maka yang terjadi adalah kerugian yang didapat bukanlah keberuntungan.

\section{Menanamkan Mental Disiplin pada Santri melalui Program Kewirausahaan}

Menanamkan mental disiplin kepada santri dilakukan dengan cara memberikan tugas proyek kepada santri dalam satu tim, dimana sudah ditentukan time achedulenya oleh mentor, apabila dalam satu tim ada yang tidak disiplin, maka proyek tersebut hasilnya tidak maksimal. Misalnya dalam bidang bisnis batik, apabila di bagian tim desain tidak disiplin waktu, maka yang terjadi di bagian pewarnaan akan terkendala. Waktu pun terbuang sia-sia dan target tanggal jadinya produk pun akan mundur.

\section{Menumbuhkan Jiwa Kreatif, Inovatif, dan Berani Mengambil Resiko}

Pembentukan jiwa kreatif pada santri dilakukan dengan memberikan modal kepada santri, lalu santri membuat perencanaan, melakukan kegiatan produksi, sampai dengan merancang strategi dalam memasarkan produk-produknya. Proses pembelajaran kreatif dan inovatif dilakukan dengan cara mentor memberikan keluasan kepada para santri untuk memproduksi batik dengan desain dan warna yang mereka inginkan, dengan cara seperti itu santri akan bangga dan puas dengan hasil atau karya mereka sendiri. tidak hanya produksi batik, para mentor juga membebaskan santri di setiap kelompok untuk memilih dan menentukan jenis buah yang akan dikelola untuk dijadikan sari buah dan dijual.

Jenis bahan-bahan yang akan dikelola sebelumnya dirapatkan dulu di dalam kelompok, sehingga terdapat kesepakatan dalam kelompok. Dalam menentukan jenis barang yang akan dijual santri akan dihadapkan pada dua pilihan yang pertama, mereka akan mengikuti tren atau santri akan membuat produk yang sebelumnya belum ada dipesaran. Tentunya akan ada 
Jurnal Pendidikan Ekonomi: Jurnal Ilmiah Ilmu Pendidikan, Ilmu Ekonomi, dan Ilmu Sosial ISSN 1907-9990 | E-ISSN 2548-7175 | Volume 14 Nomer 1 (2020)

DOI: 10.19184/jpe.v14i1.12035

konsekuensi masing-masing dari setiap pilihan yang mereka sepakati. Apabila mengikuti tren, maka barang yang mereka jual akan habis. Sebaliknya, apabila mereka membuat inovasi baru belum tentu dapat habis dengan cepat.

\section{Pembahasan}

Hasil penelitian ini menunjukkan bahwa Pembelajaran kewirausahaan di pondok pesantren Mabadi'ul Ihsan dilakukan dengan cara konsep-konsep kewirausahaan diintegrasikan dengan mata pelajaran umum seperti matematika, IPA, Bahasa Indonesia, Agama, Ekonomi disesuaikan dengan karakteristik suatu tema pembelajaran tertentu. pengintegrasian konsepkonsep kewirausahaan di kelas disesuaikan dengan sifat dan karakteristik muatan pembelajaran yang harus dicapai santri, pada mata pelajaran agama guru mengajarkan tentang bersikap jujur dan bersedekah dari hasil penjualan yang didapat. Pembelajaran kewirausahaan di pondok pesantren Mabadi'ul Ihsan juga dilakukan dengan cara praktik bisnis. Dari analisis diatas mengenai pengintegrasian mata pelajaran kewirausahaan santri pondok pesantren Mabadi'ul Ihsan, sejalan dengan pendapat Wibowo (2011:61) bahwa program pendidikan kewirausahaan di sekolah dapat diintegrasikan melalui berbagai aspek, yaitu diintegrasikan dalam seluruh mata pelajaran, memadukan dengan kegiatan ekstrakurikuler, pendidikan kewirausahaan melalui pengembangan diri, pengintegrasian dalam buku ajar, pengintegrasian melalui kultur sekolah dan pengintegrasian melalui muatan lokal.

Berdasarkan hasil penelitian yang telah dilakukan oleh peneliti Business Center merupakan salah satu strategi secara bertatap muka langsung dengan konsumen. Dalam melakukan praktik business center, santri mendapatkan pengalaman langsung berupa: pertama, santri melakukan observasi pasar untuk mengetahui apa kebutuhan konsumen terhadap barang keperluan sehari-hari. Kedua, berdasarkan observasi pasar, santri dapat menginventarisir kebutuhan barang yang harus disediakan untuk memenuhi kebutuhan konsumen. Ketiga, santri menjual barang langsung kepada konsumen dengan harga yang sudah ditetapkan. Keempat, santri dapat melakukan pembukuan terhadap transaksi yang dilakukan. Kelima, santri dapat mengelola keuangan dan keuntungan yang diperoleh. Dari analisis diatas mengenai Business center sejalan dengan pendapat Direktorat PSMK (2008:70) bahwa terdapat komponen penunjang untuk mewujudkan business center diantaranya manajemen operasional, sumber daya manusia, kurikulum, sarana dan prasarana, investasi dan keuangan, kerjasama dengan institusi lain, proses pembelajaran melalui kegiatan produksi, kewirausahaan, produk barang dan jasa.

Ekstrakurikuler penting untuk mengembangkan jiwa kreatifitas santri. Pondok Pesantren memberikan keterampilan dengan tujuan membekali santri untuk beraktifitas sesuai dengan bakat dan potensi yang dimiliki santri. Berdasarkan hasil dari penelitian terdapat Pelatihan keterampilan yang meliputi:

Pelatihan batik, dilaksanakan setiap hari minggu pada pukul 08.00-10.00 yang diampu oleh ustadzah Anis Zulaikhah. Materi membatik berasal dari buku tentang batik, internet dan dari video youtube. Dengan keterampilan berupa batik cap, batik tulis dan batik alam. Kegiatan proses membatik, guru mengajarkan proses afdruk, pembuatan pola atau desain hingga proses pencetaan.

Pelatihan mengolah makanan dan minuman sari buah Pelatihan kewirausahaan ekstrakurikuler pengelolaan makanan dan minuman sari buah diampu oleh ustadzah dewi, program pelatihan ini termasuk dalam program yang banyak peminatnya yang di dominasi oleh santri putri. Pembelajaran pengelolaan makanan dan minuman sari buah di pondok pesantren Mabadi'ul Ihsan dilaksanakan hari minggu, dengan Guru mendemontrasikan materi dengan menggunakan metode ceramah dengan contoh bahan-bahan yang akan diolah untuk dijadikan makanan dan minuman sari buah. Setelah itu santri mulai kegiatan praktik dengan pengawasan guru. pimpinan pondok pesantren Mabadi'ul Ihsan juga mengundang pelatih dari Disperindag untuk melatih para santri, dalam pelatihan ini santri dilatih mulai dari membuat berbagai snack dan minuman dengan bahan dasar buah-buahan seperti santri dilatih membuat makanan mie dari bahan buah naga, santri dilatih untuk membuat berbagai macam snack atau camilan dari bahan 
Jurnal Pendidikan Ekonomi: Jurnal Ilmiah Ilmu Pendidikan, Ilmu Ekonomi, dan Ilmu Sosial ISSN 1907-9990 | E-ISSN 2548-7175 | Volume 14 Nomer 1 (2020)

DOI: 10.19184/jpe.v14i1.12035

makaroni yang disajikan dengan varian rasa yang berbeda mulai dari rasa pedas, asin, manis, dan jagung. Selanjutnya santri juga dilatih bagaimana membuat minuman sari buah yang sehat untuk dikonsumsi. Adanya pelatihan ekstrakurikuler dapat memperluas pengetahuan para santri, hal ini sesuai dengan teori dari kegiatan ekstrakurikuler menurut Direktorat Pendidikan Menengah Kejuruan (dalam Suryosubroto, 2009:287), kegiatan yang dilakukan di luar jam pelajaran tatap muka, dilaksanakan di sekolah atau di luar sekolah agar lebih memperkaya dan memperluas wawasan pengetahuan dan kemampuan yang telah dipelajari dari berbagai mata pelajaran.

Strategi Pondok Pesantren Mabadi'ul Ihsan adalah dengan melibatkan santri pada kegiatan produksi batik dan pengelolaan makanan dan minuman sari buah. Hal ini sangat efektif dalam mengarahkan santri untuk mencapai kompetensi yang dikembangkan. Berdasarkan hasil penelitian yang telah dilakukan oleh peneliti unit produksi bagi santri dapat berfungsi sebagai tempat meningkatkan ketrampilan diantaranya santri benar-benar terjun di lapangan pekerjaan. Santri dapat merencanakan pekerjaan, mengontrol kualitas dan menjual barang hasil dari produksi batik, makanan dan minuman sari buah yang mereka hasilkan. Unit produksi ini santri juga dilatih untuk kerja keras dan disiplin dalam bekerja yang merupakan pembentukan jiwa wiraswasta. Serta dengan pelaksanaan unit produksi secara profesional maka santri setelah lulus akan mempunyai pengetahuan, ketrampilan dan sikap yang lebih sesuai tuntutan pasar kerja. Dari analisis diatas mengenai unit produksi sejalan dengan pendapat (Dikmenjur, 2007), tujuan penyelenggaraan kegiatan unit produksi adalah: Wahana pelatihan berbasis produksi atau jasa bagi siswa, Wahana menumbuhkan dan mengembangkan jiwa wirausaha guru dan siswa pada SMK/MAK, Sarana praktik produktif secara langsung bagi siswa.

Penanaman nilai karakter pun dilakukan secara bertahap dimulai dari memberikan pengetahuan kepada santri tentang karakter, kemudian santri mengaplikasikannya melalui pelaksanaan kegiatan bisnis. Kegiatan penanaman karakter dilakukan secara berulang-ulang, sehingga menjadi sebuah kebiasaan yang baik bagi santri. Jadi, di pondok pesantren Mabadi'ul Ihsan karakter tidak hanya sebatas pada pengetahuan saja, tetapi juga dilaksanakan dan menjadi sebuah kebiasaan. Dalam pelaksanaan penanaman nilai kewirausahaan para mentor benar-benar mendampingi dan memperhatikan santrinya.

Berdasarkan hasil penelitian yang peneliti lakukan ada beberapa nilai-nilai kewirausahaan yang sudah diterapkan kepada santri pondok pesantren Mabadi'ul Ihsan, yaitu: percaya diri, kepemimpinan, tanggung jawab, disiplin, kreatif, inovatif, berani mengambil resiko, berorientasi pada tugas dan hasil.

\section{PENUTUP}

Berdasarkan hasil penelitian dan pembahasan mengenai stratgei transformasi nilai kewirausahaan di Pondok Pesantren Mabadi'ul Ihsan, dapat ditarik kesimpulan bahwa strategi yang dilakukan oleh Pondok Pesantren Mabadi'ul Ihsan adalah pertama, diintegrasikan pada mata pelajaran, pengintegrasian konsep-konsep kewirausahaan di kelas disesuaikan dengan sifat dan karakteristik muatan pembelajaran yang harus dicapai santri, pada mata pelajaran agama guru mengajarkan tentang bersikap jujur dan bersedekah dari hasil penjualan yang didapat. Kedua, Business center santri dilibatkan ke dalam unit usaha yang berada di lingkungan pesantren diantaranya Mihamart dan kantin pesantren, unit usaha tersebut mampu mencetak santri yang mempunyai nilai kewirausahaan seperti percaya diri, dan berani menanggung resiko. Hal ini bisa dilihat dari kegiatan santri mulai dari melayani pembeli, hal ini santri akan memiliki nilai percaya diri untuk tampil dihadapan pembeli secara langsung. Santri juga memiliki nilai berani mengambil resiko, mulai dari proses laporan keuangan dimana setiap minggunya harus melaporkan kepada pengasuh, hal ini akan membuat santri lebih tanggung jawab atas apa yang sudah mereka laporkan. Ketiga ekstrakurikuler yaitu pelatihan batik dan pengelolaan makanan ringan dan minuman dari sari buah asli, pelatihan ini akan melatih santri mempunyai kemampuan atau keterampilan khusus, dengan keterampilan yang dimiliki santri akan tertanam nilai keorisinilan yaitu keratif dan inovatif. 
Keempat santri diikutsertakan dalam pengelolaan unit produksi, unit produksi yang dikelola oleh pesantren antara lain unit produksi Miha Batik, produksi makanan ringan dan minuman sari buah asli. Unit produksi ini mampu mencetak santri yang mempunyai nilai kewirausahaan seperti berani mengambil resiko dan berorientasi pada tugas dan hasil. Hal ini bisa dilihat dari proses pengelolaan produksi batik dan juga olahan makanan dan minuman dimana dalam proses pengelolaannya, santri harus disiplin dan berhati-hati untuk memperoleh produk yang benar-benar diterima oleh semua orang. Selanjutnya tidak hanya memproduksi saja, santri juga mempromosikan hasil produksinya dengan cara mengikuti kegiatan festivalfestival dan mempromosikan kepada para tamu-tamu yang datang di pesantren dengan cara memberikan buah tangan seperti udeg, dan souvenir dari bahan batik yang dibuat oleh santri. Hal ini secara tidak langsung akan tertanam nilai kewirausahaan yaitu berorientasi pada tugas dan hasil.

Berdasarkan hasil kesimpulan dari penelitian ini maka dapat diberikan saran kepada pengelola Pondok Pesantren Mabadi'ul Ihsan. Pertama, Program pelatihan kewirausahaan bisa menjadi program wajib Pondok Pesantren Mabadi'ul Ihsan. Kedua, semua santri diharuskan mengikuti program kewirausahaan yang ada di Pondok Pesantren Mabadi'ul Ihsan.

\section{DAFTAR PUSTAKA}

Direktorat PSMK. (2008). Kewirausahaan dalam Kurikulum SMK. Makalah disajikan dalam Seminar Nasional Wirausaha Kuliner, di Jurusan Teknologi Industri, Fakultas Teknik, Universitas Negeri Malang

Harapandi, dkk. 2007. Modernisasi Pesantren. Jakarta:Balai Penelitian dan Pengembangan Agama

Mujib, M dan Muhaimin. 1993. Pemikiran Pendidikan Islam. Bandung: Trigenda Karya

Mulyani, Endang dkk. 2010. Pengembangan Pendidikan Kewirausahaan. Jakarta. Balai Pelatihan dan Pengembangan Pusat Kurikulum.

Sadulloh, U. 2007. Pengantar Filsafat Pendidikan. Bandung: Alfabeta.

Sahabuddin, R. 2014. Transformasi \& Internalisasi Nilai-Nilai Kewirausahaan. Makassar: Rumah Buku Cara Baca

Suryana. 2006. Kewirausahaan Kiat dan Proses Menuju Sukses. Jakarta: Salemba Empat.

Praktiknyo. Yanto, S. 2002. Pengantar Kewirausahaan dan Manajemen Bisnis Kecil. Jakarta: Prenhalindo. 